Research Article

\title{
NITROGEN AND PLANT DENSITY EFFECT ON MAIZE YIELD AND YIELD TRAITS
}

\author{
Adnan Khanzada, Murad Ali Khan and Mohammad Akmal \\ Department of Agronomy, \\ University of Agriculture, Peshawar
}

*Corresponding author: adnankhanzada1985@yahoo.com

\begin{abstract}
The objective of this research was to study the response of maize Local Vs Commercial hybrid to various levels of nitrogen $(\mathrm{N})$ and plant density (D) for yield $\left(\mathrm{Kg} \mathrm{ha}^{-1}\right)$. Maize local hybrid (Baber) and Commercial hybrid (Poineer3025) were planted using four levels of nitrogen $\left(00,75,150,225 \mathrm{~kg} \mathrm{ha}^{-1}\right)$ and three plant densities $(74000,95000$ and $133000 \mathrm{ha}^{-1}$ ) at Agronomy Research Farm Malakandher, University of Agriculture Peshawar during summer 2009. Randomized Complete Block Design with split plot arrangement replicated three times was used. Sowing was done by hand at uniform row spacing $75 \mathrm{~cm}$ apart \& plant densities were maintained at $10 \mathrm{~cm}, 14 \mathrm{~cm}$ and $18 \mathrm{~cm}$ distances in rows, respectively. Results revealed that varieties did not differ $(\mathrm{p}<0.05)$ in yield or its traits, however, $\mathrm{N}$ showed marked difference in the canopy green area index (GAI), plant height, ear per plant, grains ear ${ }^{-1}$ including $^{-1}$ thousand grains weight. Plant densities also showed marked changes in the GAI, ear plant ${ }^{-1}$, grains number ear ${ }^{-1}$, grain rows ear ${ }^{-1}, 1000$ grains weight that affected grain yield. The interactions of treatments were found significant $(\mathrm{p}<0.05)$ for grain yield due to differences in yield contributing traits. The study suggested that irrespective of variety, higher $\mathrm{N} 225 \mathrm{~kg} \mathrm{ha}^{-1}$ under the D 95,000 ha ${ }^{-1}$ contributed towards higher yield with relatively higher biomass. It is obvious to planting maize at $14 \mathrm{~cm}$ distances within $0.75 \mathrm{~m}$ rows in Peshawar. Nonetheless, varieties both local and/or commercial have shown almost a similar potential under the applied inputs and climate of the area.
\end{abstract}

Key words: $\mathrm{N}$ rates, plant density, local and commercial hybrid, yield and traits

\section{Introduction}

Maize (Zea mays L.), the leading summer crop of Pakistan, is equally famous in rest of the world agriculture system. The national average yield of maize in Pakistan is very low $\left(2984 \mathrm{~kg} \mathrm{ha}^{-1}\right)$ with a further half of the national average yield $(1590 \mathrm{~kg} \mathrm{ha}$ ${ }^{1}$ ) in Khyber Pakhtunkhwa [1]. Besides the seasonal water shortage, the reason of this low yield could be associated to poor soil organic matter and either low or inappropriate nutrients application to the crop especially the nitrogen. Density also matter for lower production [2] that either not properly maintained after sowing and/or does not meet the required density during anthesis [3]. The shift affinity from an open pollinated variety to hybrid has increased in the cultivation for the region. However, sufficient nutrients application to the hybrids as per crop and soil demand is still stagnant due to either shortage at sowing time in the market and/or poor economic status of the local growers [4]. Similarly higher seed cost of commercial than the local hybrids limited growers to maintain the desired density under the circumstances if moisture has been highly depleted at the time of planting and/or water availability limits the crop establishment in the early growth and development phase [3, 5]. Maize roots have been identified the highly sensitive in response to moisture in the early establishment phase of growth [6, 7]. It is obvious that a good commercial hybrid might not perform as to the expectation of growers in the prevailing situations if the applied inputs not meet the crop requirements and/or the abrupt changes in weather and climate make the plant inefficient to perform accordingly e.g. abrupt fluctuations in seasonal temperatures at anthesis and grain development, short duration stress of heat and drought in day time in hot summer and/or the nights and day temperatures change, nutrients application rates and combination over the growth period of plants, seedbed preparation equipment and sowing method and the essential post cultivation management practices. From partial to a complete failure in germination and achieved the desired plant stand has been frequently observed in commercial hybrid [4]. Significant variation in yield has also been observed in different varieties [8]. Difference in soil nutritional status of a field within a location has also caused significant difference in productivity. Minor shortage of a soil nutrient at specific growth stage of the plant has also decreased in the productivity [9].

To maintain the desired density during the crop growth is a problem in the area and it has remained a question since long especially for the maize growers. Because maize has been contributed for green fodder in the summer and growers were used to thin-out 
plants in early growth stages. In remote area and at higher elevation, farmers are used to plant maize with relatively high density to create opportunity for green fodder during the maize weeding. Moisture loss at the sowing time and/or outbreak of moon-soon rains during the crop growth and development phase with borer attack on young plants are major hazard to sustain the desired plant density in the area. Efficiency of planting methods and equipment do play a promising role in maintaining the desired plant density for the optimum productivity. Struggles are therefore essential to optimize the optimum density for higher production in area to utilize maximum solar light for production [5, 10]. We tried to compare a local and a commercial hybrid for yield and traits with traditional production system at different density and $\mathrm{N}$ application.

Key words: Plant density, $\mathrm{N}$ rates, Varieties, Maize yield, Yield traits

\section{Materials and Methods}

Field experiment was conducted on an ecotype, Tarnab soil series (fine salty, mixed hyper-thermic udic haplustepts). The study site is about $1200 \mathrm{~km}$ in north of Indian oceans at an altitude of $350 \mathrm{~m}$, latitude $34.01^{\mathrm{O}} \mathrm{N}$ at Agric. Res. Farm, University of Agricultural, Peshawar, Pakistan. Topography of the experimental location can be described as gently sloping from north to south. Mountains surround the Peshawar valley and two rivers flow in to provide water for irrigating the crops. Drought occurred in south due to water limitation of the annual precipitation ranges from 250 to $1500 \mathrm{~mm}$. Irrigation facility also limits crop water demand from mild to moderate from north to south in the area. Soil of the site is generally clay loam, low in organic matter $(0.15 \%)$ and moderately alkaline $(\mathrm{pH} 8.15)$ with total $\mathrm{N}$ content about of about 0.7 to $1.05 \%$.

The experiment was conducted in summer during 2009 in randomized complete block design with split plot arrangement replicated three times. A sub-plot was measured $4.0 \mathrm{~m}$ in length and $4.5 \mathrm{~m}$ in width for accommodating six rows at $0.75 \mathrm{~m}$ distance in the NS direction. Two maize hybrids, a local (cv. Baber) and commercial (cv. P-3025), were planted as main plot treatment. The nitrogen $\left(\mathrm{N}=0,75,150,225 \mathrm{~kg} \mathrm{ha}^{-1}\right)$ and plant density $\left(\mathrm{D}=74,000,95,000,133,000 \mathrm{ha}^{-1}\right)$ were assigned as subplot treatments. The sowing was done manually with drill in lines $0.75 \mathrm{~m}$ apart on June 21, 2009. Phosphorus was applied @ 100 kg ha ${ }^{1}$ uniformly as basal application during seed-bed preparation. Nitrogen was applied in two split doses; half at sowing during seedbed preparation and half (25 days after sowing $=$ DAS $)$ with first weeding to the crop and subsequently irrigated. Planting was done with uniform seed rate $\left(33 \mathrm{~kg} \mathrm{ha}^{-1}\right)$ and the desired density was maintained manually by thin-out the extra plants from each row of the experimental unit (between 19 and 22 DAS). For the desired plant density, 10,14 and $18 \mathrm{~cm}$ plant to plant distances within each row, by leaving 22, 28 and 40 plants row 1 , were maintained during weeding. This produces approximately 74, 95 and 133 thousand plants $\mathrm{ha}^{-1}$, respectively. All other agronomic practices were kept constant. Growth phenology and yield were focused on two central rows in an experimental unit while the yield traits were recorded at harvest on ten uniformly representative plants. The final yield and dry matter was observed in two central rows. Canopy green area index (GAI) was recorded on non-destructively a week before the harvesting at physiological maturity with plant canopy analyzer (LI-2000, LI-COR, USA). Grain yield $\left(\mathrm{kg} \mathrm{ha}^{-1}\right)$ was estimated from two central rows by threshing and shelling all grains and adjusting with $16 \%$ grain moisture contents (Dickey John's, Grain moisture Tester, USA).

All data were subject to analysis of variance (ANOVA) using ANOVA model of SAS [11] for measurements made in the field. Analysis were made using appropriate model for randomized complete block design with split plot arrangement and means were tested using LSD $(\mathrm{p}<0.05)$ where found significant.

\section{Results and Discussion}

Canopy green area index (GAI) of maize hybrids is shown in Table 1. Meditation of the data revealed that hybrids did not differ $(\mathrm{p}<0.05)$ in GAI. However, the treatments plant density (D) and nitrogen (N) were found significant for GAI. The maximum GAI (3.46) was observed in higher D $\left(133,000 \mathrm{ha}^{-1}\right)$ and the minimum in lower D $\left(74,000 \mathrm{ha}^{-1}\right)$. Likewise, the highest $\mathrm{N} 225 \mathrm{~kg} \mathrm{ha}^{-1}$ showed the highest GAI (3.22) which did not differ $(\mathrm{p}<0.05)$ than $150 \mathrm{~kg} \mathrm{ha}^{-1}$. The control treatment showed the lowest (2.18) GAI. The only interaction of treatments (V x D) was significant for the GAI (Fig. 1a). Generally, the GAI was observed lower at the lower D and higher at the maximum D. Interactive effect of treatments $V \times D$ revealed a high GAI (3.78) for Baber under D $133,000 \mathrm{ha}^{-1}$ and lower GAI (2.37) for P-3025. A similar trend was noted with high for local Baber and low for the commercial P-3025 under D 95,000 ha ${ }^{-1}$. Contrary to that, commercial over local showed a higher GAI in the early establishment phase. All other interactions were non-significant $(\mathrm{p}<0.05)$. The results are in agreement literature [12] to the extent it has reported that canopy area index expands with increasing population ( 4.5 to 13.5 plants $\mathrm{m}^{-2}$ ) but the higher GAI of local vs. commercial might be 
associated to their canopy structure. Baber showed taller plants than P-3025 (data not shown) might have also produced higher nodes and hence reflected a relatively denser canopy.

The ear number plant $^{-1}$ indicated a non-significant effect between the local and commercial hybrid (Table 2). However, both treatments D and $\mathrm{N}$ showed a significant change $(\mathrm{P}<0.05)$ in the ear number. The lower the density the higher the ear number and vice versa. Ear number was about 1.00 in D 74,000 hawhich subsequently decreased $(\mathrm{p}<0.05)$ to 0.74 under D $133,000 \mathrm{ha}^{-1}$. Literature also supports that increased density from optimum to the maximum increased barren plants per unit area and hence we observed a lower ear number per unit area [3]. Similarly, a higher ear number (1.07) was observed in the highest $\mathrm{N} 225 \mathrm{~kg} \mathrm{ha}^{-1}$ treatment which subsequently decreased $(\mathrm{p}<0.05)$ when $\mathrm{N}$ application limited to $75 \mathrm{~kg} \mathrm{ha}^{-1}$. The control treatment was found non-significant to the lowest $\mathrm{N}$ application. Treatment $\mathrm{D} \times \mathrm{N}$ interactions also showed a significant response for the ear number (Fig. 1b). Increased $\mathrm{N}$ from control and/or the lowest $75 \mathrm{~kg} \mathrm{ha}^{-1}$ showed an increase in the ear number in almost all D treatments but in different fashions. The lower density $\left(74,000 \mathrm{ha}^{-1}\right)$ showed high ear number plant ${ }^{-1}$ which remained high under either in the control and/or all $\mathrm{N}$ rates. The medium density $\left(95,000 \mathrm{ha}^{-1}\right)$ matched in ear number with the higher D $(133,000$ $\mathrm{ha}^{-1}$ ) in control and/or lower $\mathrm{N}$ rate $75 \mathrm{~kg} \mathrm{ha}^{-1}$ nonetheless a further $\mathrm{N}$ increase showed a reduction in ear number per plant under higher D $\left(133,000 \mathrm{ha}^{-}\right.$ $\left.{ }^{1}\right)$. All other interactions were non-significant $(p<0.05)$. An increase to a decrease in the ear number is a common phenomenon and associated with too many factors e.g. varieties, soil nutrition and climate. However, the suppressive effect of the denser population on yielding ear plant ${ }^{-1}$ has also been reported in literature [13] which is totally different from the findings [14]. They have reported that lighter population increases ear plant ${ }^{-1}$. High ear number plant $^{-1}$ in lighter population might be due to less competition for resources e.g. light by the over shaded leaves in the canopy or higher demand of the sink than source. It is quite frequently reported that increased $\mathrm{N}$ application sowed an increase in ear plant $^{-1}$ which might be that demand on $\mathrm{N}$ is met by the source for a sink [15].

Grain number ear ${ }^{-1}$ data are given in Table 3. Statistical analysis of the data revealed a non-

Table 1. Canopy green area index (GAI) of maize varieties (V) affected by plant density (D) and nitrogen (N).

\begin{tabular}{|c|c|c|c|c|c|c|c|}
\hline \multirow[t]{2}{*}{ Variety (V) } & \multirow[t]{2}{*}{ D $\left(000 \mathrm{ha}^{-1}\right)$} & & \multicolumn{4}{|c|}{$\mathrm{N}\left(\mathrm{kg} \mathrm{ha}^{-1}\right)$} & \multirow{2}{*}{ Mean } \\
\hline & & & 00 & 75 & 150 & 225 & \\
\hline & & & \multicolumn{4}{|c|}{$\mathrm{D} \times \mathrm{V} \times \mathrm{N}$} & $\mathrm{V} \times \mathrm{D}$ \\
\hline \multirow[t]{3}{*}{ P-3025 } & 74 & & 1.8 & 2.2 & 2.8 & 2.9 & $2.4 \mathrm{~d}$ \\
\hline & 95 & & 1.9 & 2.1 & 2.7 & 2.8 & $2.4 \mathrm{de}$ \\
\hline & 133 & & 2.8 & 3.0 & 3.4 & 3.4 & $3.1 \mathrm{~b}$ \\
\hline \multirow[t]{4}{*}{ Baber } & 74 & & 1.8 & 2.0 & 2.4 & 2.6 & $2.2 \mathrm{e}$ \\
\hline & 95 & & 2.0 & 2.8 & 2.9 & 3.1 & $2.7 \mathrm{c}$ \\
\hline & 133 & & 2.8 & 3.1 & 4.6 & 4.6 & $3.8 \mathrm{a}$ \\
\hline & & & \multicolumn{4}{|c|}{$\mathrm{VxN}$} & $\mathrm{v}$ \\
\hline P-3025 & & & 2.2 & 2.4 & 3.0 & 3.0 & 2.6 \\
\hline \multirow[t]{5}{*}{ Baber } & & & 2.2 & 2.6 & 3.3 & 3.4 & 2.9 \\
\hline & & & \multicolumn{4}{|c|}{$\mathrm{D} \times \mathrm{N}$} & $\mathrm{D}$ \\
\hline & 74 & & 1.8 & 2.2 & 2.6 & 2.8 & $2.3 \mathrm{c}$ \\
\hline & 95 & & 2.0 & 2.4 & 2.8 & 2.9 & $2.5 \mathrm{~b}$ \\
\hline & 133 & & 2.8 & 3.0 & 4.0 & 3.9 & $3.5 \mathrm{a}$ \\
\hline Mean & & & $2.2 \mathrm{c}$ & $2.5 \mathrm{~b}$ & $3.1 \mathrm{a}$ & $3.2 \mathrm{a}$ & \\
\hline $\operatorname{LSD}(p \leq 0.05)$ for $\mathrm{D}$ & & $=0.1572$ & & & & & \\
\hline $\operatorname{LSD}(\mathrm{p} \leq 0.05)$ for $\mathrm{N}$ & & $=0.1815$ & & & & & \\
\hline $\operatorname{LSD}(p \leq 0.05)$ for $\mathrm{V} \times \mathrm{D}$ & & $=0.2223$ & & & & & \\
\hline
\end{tabular}


Table 2. Ear number plant ${ }^{-1}$ of the maize varieties (V) affected by plant density (D) and nitrogen (N).

\begin{tabular}{|c|c|c|c|c|c|c|}
\hline \multirow{2}{*}{ Variety (V) } & \multirow{2}{*}{$\mathrm{D}\left(000 \mathrm{ha}^{-1}\right)$} & \multicolumn{4}{|c|}{$\mathrm{N}\left(\mathrm{kg} \mathrm{ha}^{-1}\right)$} & \multirow[t]{2}{*}{ Mean } \\
\hline & & 00 & 75 & 150 & 225 & \\
\hline & & \multicolumn{4}{|c|}{$\mathrm{Dx} V \mathrm{xN}$} & $\mathrm{V} \times \mathrm{D}$ \\
\hline \multirow[t]{3}{*}{ P-3025 } & 74 & 0.9 & 0.9 & 1.1 & 1.1 & 1.0 \\
\hline & 95 & 0.7 & 0.7 & 0.8 & 1.1 & 0.9 \\
\hline & 133 & 0.6 & 0.6 & 0.7 & 0.9 & 0.7 \\
\hline \multirow[t]{4}{*}{ Baber } & 74 & 0.9 & 0.8 & 0.9 & 1.2 & 1.0 \\
\hline & 95 & 0.8 & 0.8 & 1.0 & 1.2 & 0.9 \\
\hline & 133 & 0.7 & 0.7 & 0.8 & 1.1 & 0.79 \\
\hline & & \multicolumn{4}{|c|}{$\mathrm{V} \times \mathrm{N}$} & $\mathrm{V}$ \\
\hline P-3025 & & 0.7 & 0.7 & 0.9 & 1.0 & 0.8 \\
\hline \multirow[t]{5}{*}{ Baber } & & 0.8 & 0.8 & 0.9 & 1.2 & 0.9 \\
\hline & & \multicolumn{4}{|c|}{$\mathrm{D} \times \mathrm{N}$} & D \\
\hline & 74 & 0.9 & 1.0 & 1.0 & 1.1 & $1.0 \mathrm{a}$ \\
\hline & 95 & 0.6 & 0.7 & 0.9 & 1.1 & $0.9 \mathrm{~b}$ \\
\hline & 133 & 0.6 & 0.7 & 0.8 & 1.0 & $0.7 \mathrm{c}$ \\
\hline Mean & & $0.8 \mathrm{c}$ & $0.8 \mathrm{c}$ & $0.9 \mathrm{~b}$ & $1.1 \mathrm{a}$ & \\
\hline $\mathrm{D}(\mathrm{p} \leq 0.05)$ for $\mathrm{D}$ & $=0.04506$ & & & & & \\
\hline $\mathrm{D}(\mathrm{p} \leq 0.05)$ for $\mathrm{N}$ & $=0.05204$ & & & & & \\
\hline $\mathrm{D}(\mathrm{p} \leq 0.05)$ for $\mathrm{D} \times \mathrm{N}$ & $=0.09013$ & & & & & \\
\hline
\end{tabular}

Means followed by different letters in a category are significantly different $(\mathrm{p} \leq 0.05)$ using the LSD test.

Table 3. Grain number ear ${ }^{-1}$ of the maize varieties (V) affected by plant density (D) and nitrogen (N).

\begin{tabular}{|c|c|c|c|c|c|c|}
\hline \multirow{2}{*}{ Variety (V) } & \multirow[t]{2}{*}{ D $\left(000 \mathrm{ha}^{-1}\right)$} & \multicolumn{4}{|c|}{$\mathrm{N}\left(\mathrm{kg} \mathrm{ha}^{-1}\right)$} & \multirow{2}{*}{ Mean } \\
\hline & & 00 & 75 & 150 & 225 & \\
\hline & & $\mathrm{Dx} \mathrm{V}$ & & & & $V \times D$ \\
\hline \multirow[t]{3}{*}{ P-3025 } & 74 & 273 & 293 & 322 & 326 & 303 \\
\hline & 95 & 266 & 284 & 299 & 305 & 289 \\
\hline & 133 & 253 & 265 & 285 & 294 & 274 \\
\hline \multirow[t]{4}{*}{ Baber } & 74 & 290 & 307 & 338 & 342 & 319 \\
\hline & 95 & 279 & 296 & 308 & 320 & 301 \\
\hline & 133 & 268 & 278 & 290 & 296 & 283 \\
\hline & & $\mathrm{V} \times \mathrm{N}$ & & & & $\mathrm{v}$ \\
\hline P-3025 & & 264 & 281 & 302 & 308 & 289 \\
\hline \multirow[t]{5}{*}{ Baber } & & 279 & 293 & 312 & 319 & 301 \\
\hline & & $\mathrm{D} \times \mathrm{N}$ & & & & D \\
\hline & 74 & 281 & 300 & 330 & 334 & $311 \mathrm{a}$ \\
\hline & 95 & 273 & 290 & 304 & 312 & $295 \mathrm{~b}$ \\
\hline & 133 & 261 & 272 & 288 & 295 & $279 c$ \\
\hline Mean & & $272 \mathrm{~d}$ & $287 \mathrm{c}$ & $307 \mathrm{~b}$ & $314 \mathrm{a}$ & \\
\hline
\end{tabular}

$\begin{array}{ll}\operatorname{LSD}(\mathrm{p} \leq 0.05) \text { for } \mathrm{D} & =3.692 \\ \operatorname{LSD}(\mathrm{p} \leq 0.05) \text { for } \mathrm{N} & =4.263 \\ \operatorname{LSD}(\mathrm{p} \leq 0.05) \text { for } \mathrm{D} \times \mathrm{N} & =7.383\end{array}$

Means followed by different letters in a category are significantly different $(\mathrm{p} \leq 0.05)$ using the LSD test. 

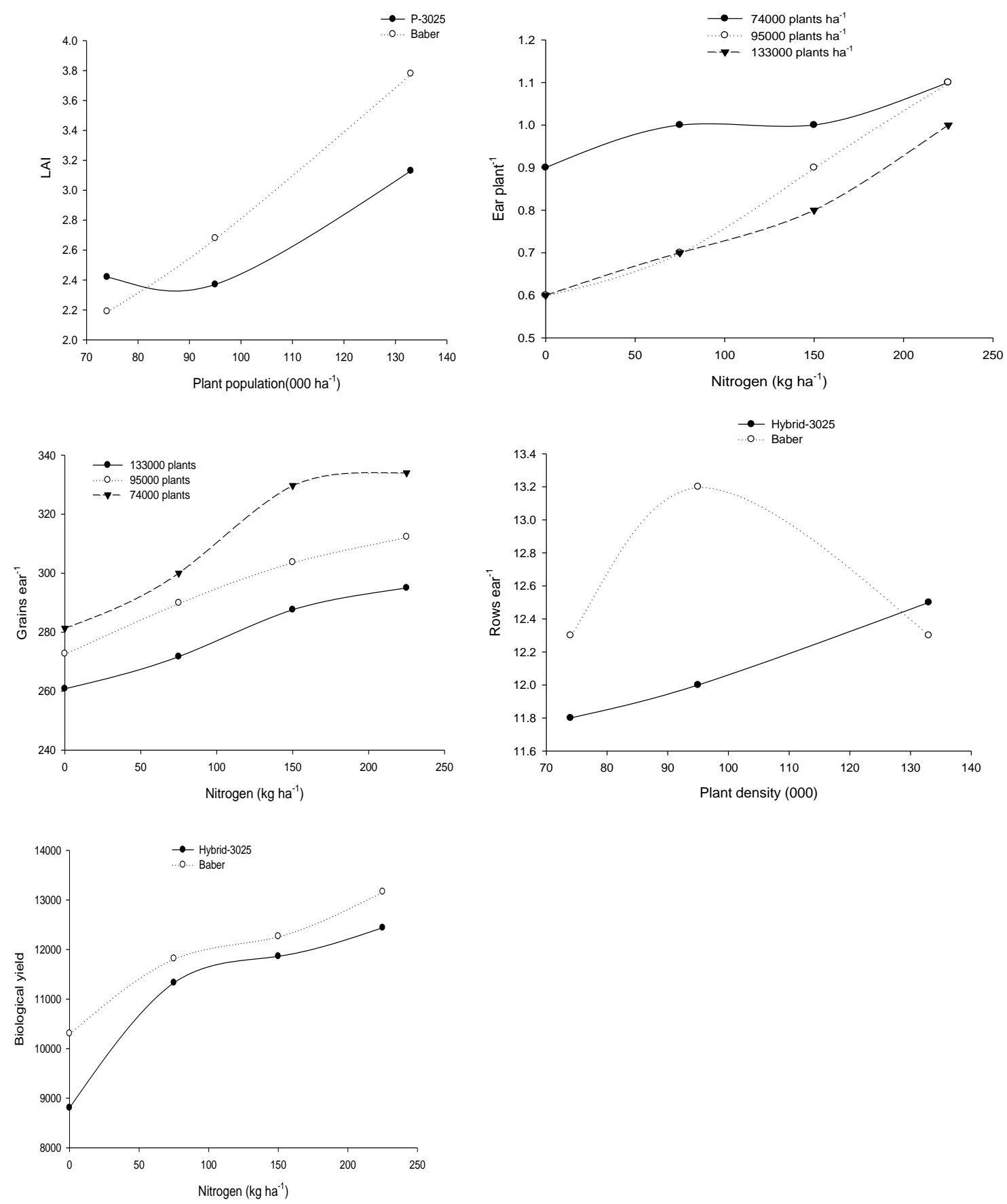

Fig. 1. Interactive effects: of treatments (a) plant density and varieties on canopy green area index, (b) plant density and $\mathrm{N}$ on ear number (plant $\left.{ }^{1}\right)$, (c) plant density and $\mathrm{N}$ on grain number $\left(\mathrm{ear}^{-1}\right)$, (d) plant density $\mathrm{x}$ variety on grain row $\left(\mathrm{ear}^{-1}\right)$, and (e) $\mathrm{N} \mathrm{x} \mathrm{variety} \mathrm{on} \mathrm{biological} \mathrm{yield}\left(\mathrm{kg} \mathrm{ha}^{-1}\right)$.

significant effect on grain number for the variety, however, the treatments $\mathrm{D}$ and $\mathrm{N}$ showed a significant response $(\mathrm{p}<0.05)$. The maximum grain number ear $^{-1}$ (311.20) was observed in D 74,000 ha ${ }^{-1}$ and the minimum (278.75) in D 133,000 ha ${ }^{-1}$. Highest
N $225 \mathrm{~kg} \mathrm{ha}^{-1}$ showed the maximum grains ear ${ }^{-1}$ (313.77) which subsequently decreased $(\mathrm{p}<0.05)$ by reducing $\mathrm{N}$ application $75 \mathrm{~kg} \mathrm{ha}^{-1}$. The minimum (271.61) grain number was reported in the control treatment. Treatments $\mathrm{N} \times \mathrm{D}$ showed a significant effect on grain number (Fig. 1c). Grains ear $^{-1}$ was 
higher in lower densities of all treatments but with increase in $\mathrm{N}$ application, grains number $\mathrm{ear}^{-1}$ increased. The maximum was observed in D 74,000 $\mathrm{ha}^{-1}$ which increased with the increasing $\mathrm{N}$ to the maximum $225 \mathrm{~kg} \mathrm{~N}^{-1}$. Similarly, the minimum grain number was observed in the D 133,000 ha-1 starting from control to the highest $\mathrm{N} 225 \mathrm{~kg} \mathrm{ha}^{-1}$. All other possible interaction were found non- significant $(p<0.05)$ for the grain number data. These results are in agreement with findings of literature [16] where it is reported more grains ear $^{-1}$ in the lower population. Similar results are also reported in the literature [17]. It is also cited [18] that higher population at low level of nitrogen had suppressed grains ear ${ }^{-1}$. Nitrogen plays a central role in grain formation, grains ear $^{-1}$ increased linearly with increased N [19]. The grain row number ear ${ }^{-1}$ data is shown in Table 4. Statistical analysis of the data showed that variety was nonsignificantly differed for row number but treatment D and $\mathrm{N}$ did vary in grain row number. The highest grain rows ear ${ }^{-1}$ (12.6) was observed for D 95,000 ha 1 , while the minimum (12) for $\mathrm{D} 74,000 \mathrm{ha}^{-1}$. Treatments N 225 and $150 \mathrm{~kg} \mathrm{ha}^{-1}$ showed the maximum grain rows ear $^{-1}$ (12.9) followed by the $\mathrm{N}$ $750 \mathrm{~kg} \mathrm{ha}^{-1}$. The minimum (11.6) grain row number was observed in control. Interaction of treatment $\mathrm{V} x$ D was significant for grain row numbers (Fig 1d). The highest (13.2) grain row number ear $^{-1}$ was recorded for variety Baber than P-3025 at $74000 \mathrm{ha}^{-1}$ and 95,000 plants ha- ${ }^{-1}$. The D 113,000 ha ${ }^{-1}$ did not show any difference in grain rows for variety $\mathrm{P}-3025$ and Baber. All other interaction were found nonsignificant $(p<0.05)$ for the grain row per ear data. Thousand grains weight $(\mathrm{g})$ was non-significant between both varieties, but did differ for the $\mathrm{D}$ and $\mathrm{N}$ (Table 5). The highest thousand grain weight (232 g) was recorded for $\mathrm{D} 74,000 \mathrm{ha}^{-1}$ and the minimum (204 g) for the D 133,000 ha ${ }^{-1}$. Likewise, the maximum thousand grain weight (233 g) was recorded for $\mathrm{N} 225 \mathrm{~kg} \mathrm{ha}^{-1}$, followed by with a significant difference for $\mathrm{N} 150 \mathrm{~kg} \mathrm{ha}^{-1}$. The minimum (201 g) thousand grains were observed in the control treatment. All other interactions were non-significant for the grain index $(\mathrm{p}<0.05)$. Some scientist $[17,20]$ have observed relatively higher grain row number ear ${ }^{-1}$ in $\mathrm{N} 150 \mathrm{~kg} \mathrm{ha}^{-1}$ which can be enhanced further with increase in the $\mathrm{N}$, because $\mathrm{N}$ is the key factor affecting vegetative as well as reproductive growth. The higher the $\mathrm{N}$ contents in plant leaves the greater would be the assimilate production [21]. A decrease in the grain index with increase in the density agreed with findings of the literature $[18,22]$. The grain weight is genetically controlled and greatly affected by the surrounding environmental factors during the grain filling.
However $\mathrm{N}$ application has increased the protein content which significantly increased the grain number and weight [23].

Data for biological yield $\left(\mathrm{kg} \mathrm{ha}^{-1}\right)$ are presented in Table 6. Statistical analysis of data showed a nonsignificant effect between the varieties. However, biological yield did differ for the treatments $\mathrm{D}$ and $\mathrm{N}$. The highest biological yield (11994 $\mathrm{kg} \mathrm{ha}^{-1}$ ) was observed for D 133,000 $\mathrm{ha}^{-1}$ and the lowest (11279 $\mathrm{kg} \mathrm{ha}^{-1}$ ) for D 74,000 ha ${ }^{-1}$. Nitrogen treatments showed the highest biological yield $\left(12803 \mathrm{~kg} \mathrm{ha}^{-1}\right)$ for $\mathrm{N} 225 \mathrm{~kg} \mathrm{ha}^{-1}$, which significantly $(\mathrm{p}<0.05)$ declined for each reduction in $\mathrm{N}$ application. The control plots showed the lowest biological yield $\left(9557.22 \mathrm{~kg} \mathrm{ha}^{-1}\right)$. The only interaction of the treatments variety $\mathrm{x} N$ was found significantly different for biological yield (Fig. 1e). Increased N increased biological yield for both varieties but with the higher rates for local than the commercial. It was expected and is quite natural that higher the density per unit the higher would be the biomass [23]. However, our findings did agree with findings of [24, 25] who have reported a positive favorable response of the biological yield with increased in the soil $\mathrm{N}$. The grain yield $\left(\mathrm{kg} \mathrm{ha}^{-1}\right)$ showed that variety did not differ from each other. However, a significant effect of $\mathrm{D}$ and $\mathrm{N}$ for grain yield was common as observed for the grain traits (Table 6). The highest grain yield (3481 kg ha ${ }^{-1}$ ) was recorded for D 95,000 ha ${ }^{-1}$ and minimum $\left(3004 \mathrm{~kg} \mathrm{ha}^{-1}\right.$ ) for the D 74,000 $\mathrm{ha}^{-1}$. The $\mathrm{N}$ $225 \mathrm{~kg} \mathrm{ha}^{-1}$ showed the highest grain yield $(3744 \mathrm{~kg}$ $\mathrm{ha}^{-1}$ ) which decreased significantly for each reduction in $\mathrm{N}$ with lowest $\left(2364 \mathrm{~kg} \mathrm{ha}^{-1}\right)$ for the control has 00 $\mathrm{kg} \mathrm{ha}^{-1}$. All interactions of the treatments were nonsignificant $(p<0.05)$ for grain yield. Our results are in contrast with those of [26] who reported that population positively influenced the grain yield in maize. Grain yield linearly increased with increased in nitrogen, reached to maximum at the highest $\mathrm{N}$. Continuous increase in grain yield with successive increase in $\mathrm{N}$ showed relatively high genetic potential of grain [3, 25, 27].

The study suggests that higher $\mathrm{N}$ might delay anthesis but enables plants to build enough biomass for the optimum production if otherwise season permits reproductive growth. Increased density and $\mathrm{N}$ have increased canopy height to yield enough biomass. Yield traits e.g. ear number plant ${ }^{-1}$, grain rows ear $^{-1}$ and grain weight were the major contributor affected by the treatments, and hence resulted the higher biological and grain yield under the high $\mathrm{N}$ rate. Density did not increase the individual plant traits but did increase on area basis which results the higher biomass as well as grain 
yield. It is suggested that maize shall be planed at 14 $\mathrm{cm}$ in $75 \mathrm{~cm}$ rows to maintain D 95,000 plants $\mathrm{ha}^{-1}$ for the optimum production. Variety does not matter but nutrients the $\mathrm{N}$ and density does matter yield.

\section{References}

1. MINFAL, (2010-11) Agriculture Static of Pakistan. Ministry of Food, Agriculture and Livestock. Govt. of Pakistan.

2. Zandi P, Naderidarbaghshahi M, Soleimani A (2012) Investigation the effect of plant density on forage yield of new corn hybrids. Internl. J. Agron. Plant Production. 3: 625-629.

3. Asim M, Akmal M, Khattak RA (2013) Maize response to yield and yield traits with different nitrogen and density under climate variability. J. Pant Nutrition. 36: 179-191.

4. Akmal M, Khattak RA, Zaman R (2009) Corn yield improvement through canopy light interception. Research Project Report Ref. No. 20-911. Higher education commission of Pakistan.

5. Asim M, Akmal M, Khan A, Farhatullah Raziuddin (2012) Rate of nitrogen application influences yield of maize at low and high population in Khyber Pakhtunkhwa. Pakistan. Pak. J. Bot. 44: 289-296.

6. Sharp RE, Davies JW (1979) Solute regulation and growth by roots and shoots of water-stressed maize plants. Planta. 146: 319-326.

7. Akmal M, Hirasawa T (2004) Growth responses of seminal roots of wheat seedlings to a reduction in the water potential of vermiculite. Plant Soil. 267:319-327.

8. Kogbe JOS, Adediran JA (2003) Influence of nitrogen, phosphorus and potassium application on the yield of maize in savanna zone of Nigeria. African J. Biotechnology. 2: 345-349.

9. Liu W, Tollenaar M (2009) Response of yield heterosis to increasing plant density in maize. Crop Sci. 49: 18071816.

10. Olson RA, Sander DH (2003) Corn production, pp. 639-686. In G.F. Sprague and J.W. Dudley (ed.) Corn and corn improvement. 3rd ed. ASA, CSSA, and SSSA, Madison, WI.

11. Steel RGD, Torrie JH, Dickey DA (1997) Principles and procedures of statistics: a biometrical approach. McGraw-Hill, USA

12. Franc B, Martina B (2000) Effect of plant population on LAI, cob characteristics and grain yield of early maturing maize cultivars. Bulletin Faculty Agric. Univ. of Maribor, Vrbanska 30, Maribor, Slovenia.

13. Plensicar M, Kustori R (2005) Corn yield and water use as influenced by irrigation level, N-rate and plant populations. Trans. Kansan Acad. Sci. 53(4): 121-127.
14. Sharma TR, Adamu IM (1984) The effect of plant population on the yield and yield attributing characters in maize (Zea mays L.). Zeitschrift fur Acker-und pflanzenbau. 153(4): 315-318.

15. Mahdi M, Al-Kaisi, Yin X (2003) Effect of nitrogen rate, irrigation rate and plant population on corn yield and water use efficiency. Agron. J. 95: 1475-1482.

16. Mayer LI, Rossini MA, Maddonni GA (2012) Interplant variation of grain yield components and kernel composition of maize grown under contrasting nitrogen supply. Field Crops Res. 125: 98-125.

17. Echarte L, Andrade FH, Sadras VO, Abbate P (2006) Kernel weight and its response to source manipulations during grain filling in Argentinean maize hybrids released in different decades. Field Crops Res. 96: 307-312.

18. Mehmood T, Saeed M (1998) Nitrogen level and plant density effects on different agro-physiological traits of maize. Pak. J. Biol. Sci. 1(4):259-263.

19. Gokmen S, Sencar O, Sakin MA (2001) Response of popcorn (Zea mays) to nitrogen and plant densities. Turkish J. Agric. and Forest. 25:15-23.

20. Hassan AA (2000) Effect of plant population density on yield and yield components of eight Egyptian maize hybrids. Bulletin of Faculty of Agriculture, University, Cairo. Egypt. No. 51: pp. 1-16.

21. Uhart SA, Andrade FH (1995) Nitrogen deficiency in maize: I. Effects on crop growth, development, dry matter partitioning, and kernel set. Crop Sci. 35:1376-1383.

22. Mukhtar T, Arif M, Hussain S, Atif M, Saleem-urRehman, Hussain K (2012) Yield and yield components of maize hybrids as influenced by plant spacing. J. Agric. Res. 50: 59-69.

23. Amano LO, Solazar AM (1989). Comparative productivity of corn and sorghum as affected by population density and nitrogen fertilization. Philippine Agric. 72: 247-254.

24. Chaudhry AU, Jamil M (1998) Determination of optimum level of nitrogen and its effect on maize (Zea mays L.) Pakistan J. Biol. Sci. 1(4): 360-362.

25. Akbar H, Miftahullah, Jan MT, Ihsanullah (2002) Yield potential of sweet corn as influenced by different levels of nitrogen and plant population. Asian J. Plant Sci. 1: 631-633.

26. Dostalek R, Hruska L (1985) Effect of crop density on production of maize seed. Rostlinna Vyroba. 31(10): 11031110.

27. William DW, Kurt DT (2002) Row width and plant density effect on corn forage hybrids. Agron. J. 94: 326330. 